\title{
Establishment of an in vitro micropropagation protocol for Mecardonia tenella
}

\author{
Liliana Marisol Alderete \\ Instituto de Floricultura INTA-Castelar \\ De los Reseros y Las Cabañas s/n (1712) \\ Buenos Aires, Argentina \\ Tel/Fax: 541144813864 \\ E-mail: limarial@hotmail.com.ar \\ Marcela Mori \\ Instituto de Floricultura INTA-Castelar \\ De los Reseros y Las Cabañas s/n (1712) \\ Buenos Aires, Argentina \\ Tel/Fax: 541144813864 \\ E-mail:mmori@cnia.inta.gov.ar \\ Adriana Kato \\ Instituto de Floricultura INTA-Castelar \\ De los Reseros y Las Cabañas s/n (1712) \\ Buenos Aires, Argentina \\ Tel/Fax: 541144813864 \\ E-mail:akato@cnia.inta.gov.ar

\section{Alejandro Salvio Escandón* \\ Instituto de Floricultura INTA-Castelar \\ De los Reseros y Las Cabañas s/n (1712) \\ Buenos Aires, Argentina \\ Tel/Fax: 541144813864 \\ E-mail: aescandon@castelar.inta.gov.ar}

Financial support: INTA proyect: number 1837.

Keywords: in vitro, micropropagation, Scrophulariaceae.

Abbreviations: BAP: benzyl amino purine

MS: Murashige-Skoog medium

NAA: naphtalen acetic acid

SAA: Sigma ${ }^{\mathrm{TM}}$

antibiotics/antifungal

Mecardonia tenella is an attractive herbaceous native plant, characterized by their intense green foliage and their abundant yellow flowers. It is a very interesting plant for pot and/or garden. A trait to improve in this species is the size of the flowers. The goal of the present paper is to study the in vitro behaviour of M. tenella and to establish a routine protocol for its micropropagation. For the in vitro establishment of $M$. tenella, nodal segments were disinfected by standard methods using ethanol/sodium hypochloride and cultured on hormonefree MS medium, supplemented with a mixture of antibiotics and an antifungal. In order to study the hormonal requirements of the species, nodal segments were cultured on basal MS supplemented with antibiotic/antifungal mixture and the following concentrations of BAP and NAA (mg/L): $0.0 ; 0.25 ; 0.5$ and 1.0. These plant regulators were tested in all possible combinations. In vitro plants growing in hormone-free medium were used as explant source. The best results were obtained in the treatments containing 0.25 and $0.5 \mathrm{mg} / \mathrm{l}$ BAP with a multiplication rate of 32 shoots per explant. The regenerated shoots rooted spontaneously. When transferred to the greenhouse, the ex vitro plants grew and flowered normally.

The Mecardonia genus belongs to the Scrophulariaceae family, composed by 37 species, five of them original of Argentina. M. tenella is an attractive herbaceous native plant characterized by its intensive green foliage and their abundant ring shaped yellow flowers (Zuloaga and Morrone, 1999). It is a very interesting plant for pot and/or garden. A trait to improve in this species is the size of the flowers. To start a breeding program applying biotechnological approaches (plant transformation or in vitro mutagenesis) the establishment of in vitro micropropagation technique is required as the first step.

*Corresponding author 
Table 1. Different combinations ANA/BAP (mg/L). The numbers indicate the average of shoots per explant recovered per treatment and the letters in bracket the main response. The descendent row indicates calli increase. The horizontal row indicates the increase of compact calli and root thickness.

\begin{tabular}{|c|c|c|c|c|}
\hline ANA/BAP & $\mathbf{0 . 0}$ & $\mathbf{0 . 2 5}$ & $\mathbf{0 . 5}$ & $\mathbf{1 . 0}$ \\
\hline $\mathbf{0 . 0}$ & $4(\mathrm{~s})$ & $32.5(\mathrm{~s})$ & $32.3(\mathrm{~s})$ & $28.9(\mathrm{~s})$ \\
\hline $\mathbf{0 . 2 5}$ & $6.5(\mathrm{rc})$ & $9.7(\mathrm{rc})$ & $9.5(\mathrm{rc})$ & $10.2(\mathrm{rc})$ \\
\hline $\mathbf{0 . 5}$ & $4.3(\mathrm{rc})$ & $8.2(\mathrm{rc})$ & $7.8(\mathrm{rc})$ & $7.8(\mathrm{rc})$ \\
\hline $\mathbf{1 . 0}$ & $3.9(\mathrm{rc})$ & $2.0(\mathrm{rc})$ & $2.9(\mathrm{rc})$ & $1(\mathrm{rc})$ \\
\hline
\end{tabular}

This fact converts the tissue culture in another relevant tool of the plant breeding process. In this sense, the micropropagation of selected or improved plants allows the permanent propagation of selected traits within a specific genotype. Other advantages of the technique are the propagation rate, the space exploitation, the improvement of the sanitary conditions of the plants and the facilitation of international germplasm exchange.

A revision of the literature showed no previous report on tissue culture of this genus. Consequently, the development of in vitro tissue culture techniques will increase the scarce knowledge about the physiology of this native germplasm with potential relevance as an ornamental crop. In this sense, the adjustment of a micropropagation protocol is necessary to begin a breeding program applying biotechnological tools, as, for example, in vitro polyploidization (Notsuka et al. 2000; Horn, 2002).

The present study reports a reliable protocol for the in vitro propagation of $M$. tenella. This is done in the context of a native ornamental germplasm breeding program and based on previous reports of in vitro multiplication of other Scrophulariaceae species, such as Scoparia montevidiensis (Escandón et al. 2005) and Bacopa monnerii (Escandón et al. 2004).

\section{MATERIALS AND METHODS}

\section{Plant material and disinfection protocol}

Cloned plants from the $M$. tenella accession number 20021120A2 were used as source of the nodal segments employed as explants. The donor plants were cultured under greenhouse conditions and were pre-treated three times with an antifungal solution (Captan ${ }^{\mathrm{TM}} /$ Benomil $^{\mathrm{TM}}, 1$ $\mathrm{g} / \mathrm{L}$ each).

The explant disinfection was carried out according to the following scheme:

a) Submersion in ethanol $70 \%$ during 60 seconds.

b) Mixing with $\mathrm{NaClO} 25 \%$ /Tween $80 \quad 0.01 \%$ during 25 min.

c) Rinsing 3 times with sterile distilled water.

\section{Culture conditions and media}

For the M. tenella in vitro introduction, the explants were cultured onto complete hormone-free MS (Murashige and Skoog, 1962), supplemented with $20.0 \mathrm{~g} / \mathrm{L}$ sucrose with and without the addition of the SAA mixture $1 \mathrm{X}$. The $\mathrm{pH}$ was adjusted to 5.7 with $1 \mathrm{~N} \mathrm{KOH}$.

To study the in vitro behaviour of this Scrophulariaceae, nodal segments from the in vitro cultured plants were transferred to the same basal medium supplemented by 20.0 $\mathrm{g} / \mathrm{L}$ sucrose, the 1X SAA mixture and the following concentrations of NAA and BAP $(\mathrm{mg} / \mathrm{L}): 0.0 ; 0.25 ; 0.5$ and 1.0 , in all possible combinations, at a $\mathrm{pH}=5.7$. In the subsequent assay, nodal segments from in vitro plants cultured on hormone-free MS, were transferred to the same medium, but in this opportunity supplemented with 0.25 $\mathrm{mg} / \mathrm{L}$ BAP. The explant number per treatment was twentyfive. During the three experiments, the explants were cultured under a photoperiod of $16 \mathrm{hrs}$ light, with an intensity of 3000 lux (fluorescent tubes); the room culture temperature was $21 \pm 2^{\circ} \mathrm{C}$.

The acclimatization step was carried out transferring three or four centimetres length rooted plantlets to $8.0 \mathrm{~cm}$ diameter pots containing peat, perlite and vermiculite $3: 1: 1$ $(\mathrm{V} / \mathrm{V})$ (Escandón et al. 2003). These plants were maintained inside the humidity chamber. The nylon bags used to make the humidity chamber were gently perforated once per day until no condensation was detected inside them. Afterwards, the plants were grown under greenhouse conditions.

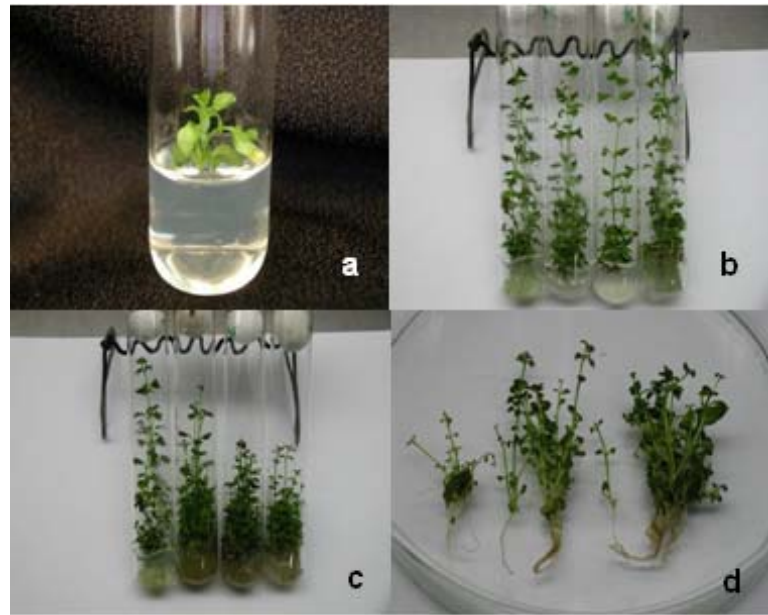

Figure 1. In vitro micropropagation progress of $\boldsymbol{M}$. tenella. (a) Initial explant growing on MS supplemented with SAA mixture $1 \mathrm{X}$.

(b) Shoots developing on MS medium supplemented with NAA only, from left to right: $0.0 ; 0.25 ; 0.5$ and $1.0 \mathrm{mg} / \mathrm{L}$. (c) Shoots developing on MS medium supplemented with BAP only, from left to right: $0.0 ; 0.25 ; 0.5$ and $1.0 \mathrm{mg} / \mathrm{L}$. (d) Plantlets from treatment $0.25 \mathrm{mg} / \mathrm{L} \mathrm{BAP}$ at the end of in vitro stage. 


\section{RESULTS AND DISCUSSION}

For the M. tenella nodal segment disinfection, the pretreatment with antifungal solution followed by the standard method of ethanol $/ \mathrm{NaClO}$ was insufficient for the in vitro establishment of this species. It was necessary to add the SAA mixture to the culture medium of the disinfected explant to avoid the development, from the portion of the nodal segment submerged into the culture medium, of the contamination that provoked the inhibition of the culture progress. In fact, only in those cases in which the nodal segments were cultured onto a medium containing the SAA mixture, it was possible to recover entire plants from the $68 \%$ of the cultured explants. This fact also indicates that the SAA mixture applied did not affect $M$. tenella nodal segment development.

Table 1 shows the responses obtained when the nodal segments of $M$. tenella were cultured on a medium supplemented with different NAA/BAP combinations. The treatment containing 0.25 and $0.5 \mathrm{mg} / \mathrm{L}$ BAP showed the best multiplication rates, with values around thirty two shoots per explant. The result was similar in the treatment with $1.0 \mathrm{mg} / \mathrm{L}$ BAP, with approximately twenty nine shoots per explants. Conversely, the treatment without BAP or containing this growth regulator combined with NAA showed multiplication rates that never surpassed eleven shoots per explant, being the less efficient those containing $1.0 \mathrm{mg} / \mathrm{L}$ NAA/BAP with only one shoot per explant. Also, Table 1 shows that an increase in the NAA/BAP ratio provoked an increment in calli induction and in the number of rooted explants, but diminished the average of shoots per explant (descendent row in Table 1). The opposite situation, that is, decreasing the NAA/BAP ratio (horizontal row in Table 1), provoked changes in the appearance of the calli, becoming more compact, and an increment in the root thickness. Although the recovered shoots from all the treatments rooted spontaneously, including those treatments without NAA, at the earliest stage of the culture the

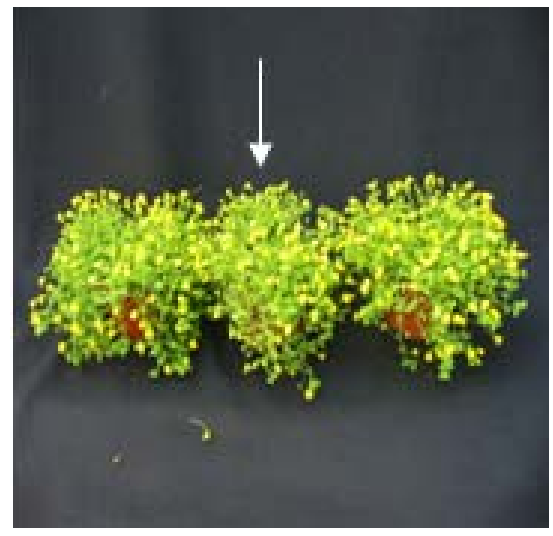

Figure 2. Ex vitro plants of $\boldsymbol{M}$. Tenella. No differences in phenology and growth habit were observed between the ex vitro plants and the in vivo propagated plant (arrowed). treatment containing only BAP did not show root development. A possible explanation of this observation would be the balance between the exogenous growth regulators and the endogenous hormones. That is, as the culture progressed, the available exogenous cytokinin was consumed or degraded, changing the NAA/BAP ratio to levels adequate for the rooting of the shoot.

In reference to the shoot multiplication rate, this parameter increased when the NAA/BAP diminished, except for those treatments containing $1.0 \mathrm{mg} / 1 \mathrm{NAA}$. It would seem that in presence of the highest NAA concentration $(1.0 \mathrm{mg} / \mathrm{L})$, the BAP concentrations tested, plus the endogenous cytokinin, were not enough to balance the auxin effect (callus and root induction).

As reported in previous works, other Scrophulariaceae species also show strict growth regulator requirements to obtain desirable results. In fact, Escandón et al. (2005) reported that $0.25 \mathrm{mg} / \mathrm{L}$ BAP was the suitable cytokinin concentration for Scoparia montevidiensis var. montevidiensis, propagation, and the addition of NAA provoked callus induction. Also, the same authors reported the relationship between hormonal requirement and in vitro behaviour of four species of Scoparia genus. Working on Bacopa monneri, Escandón et al. (2004) found a strict BAP requirement for the in vitro propagation of this species. They observed that if the BAP levels were more than 0.5 $\mathrm{mg} / \mathrm{L}$, the explants formed predominantly callus and vitrified tissue.

Figure 1 shows the progress of the M. tenella micropropagation and the different responses according to the treatments. Figure 1a shows an explant at the beginning of the culture. In this context, it is important to observe that the use of in vitro plants as explant source allows for more homogeneous material to begin testing the influence of different growth regulator combinations on the multiplication rate, avoiding the losses caused by contamination due to disinfection problems. Figures $1 \mathrm{~b}$ and $1 \mathrm{c}$ compare the response of the culture when the medium is supplemented with: $0.0 ; 0.25 ; 0.50$ and $1.0 \mathrm{mg} / \mathrm{NAA}$, without BAP (Figure 1b) or with the same increment of BAP alone (Figure 1c). It can be observed that in the NAA treatment the shoots are long and there are few shoots per tube (a maximum of 6.5 , as can be seen in Table 1). Conversely, in Figure 1c, it is possible to observe the effect of the cytokinin, the culture shows a compact aspect, and there are more shoots per tube (around 32 shoots per explant as best result). Figure 1d shows the recovered plantlets from one explant treated with BAP $0.25 \mathrm{mg} / \mathrm{L}$, in the step previous to pot transference. In Figure 1 it is possible to appreciate the numerous entire plantlets recovered with very important root development although they were treated only with a cytokinin.

Finally, Figure 2 shows an ex vitro plant maintained under greenhouse conditions. In this situation, no change in aspect and growth habits was detected. 


\section{CONCLUDING REMARKS}

The establishment of in vitro tissue culture of $M$. tenella did not show serious difficulties, except for the requirement of SAA.

As observed with other species of the Scrophulariaceae family, $M$. tenella showed a strict requirement of exogenous growth regulators.

\section{ACKNOWLEDGMENTS}

The authors thank Sandra Pitta Álvarez for the critical revision of the manuscript and Sara Ostertag for their technical support.

\section{REFERENCES}

ESCANDÓN, A.S.; MIYAJIMA, I.; ALDERETE, M.; HAGIWARA, J.C.; FACCIUTO, G.; MATA, D. and SOTO, S. Wild ornamental germplasm exploration and domestication based on biotechnological approaches. In vitro colchicine treatment to obtain a new cultivar of Scoparia montevidiensis. Electronic Journal of Biotechnology [online]. 15 August 2005, vol. 8, no. 2 [30 August 2005]. Available from Internet: http://www.ejbiotechnology.info/content/vol8/issue2/full/2/ index.html. ISSN 07173458.

ESCANDÓN, A.S.; HAGIWARA, J.C.; ALDERETE, M. and MIYAJIMA, I. Ensayos para la obtención de poliploides en Bacopa monerii. In: MORISIGUE, D. ed. II Congreso Argentino de Floricultura y Plantas Ornamentales. VI Jornadas de Floricultura. I Encuentro Latinoamericano de Floricultura $\left(26^{\text {th }}-29^{\text {th }}\right.$ October, 2004. Buenos Aires, Argentina). 2004. p. 104-106. ISBN 987521-142-7.

ESCANDÓN, A.S.; FERRARI, P.; FACCIUTO, G.; SOTO, S.; HAGIWARA, J.C. and ACEVEDO, A. Combinación de técnicas in vitro y ex vitropara la micropropagación de Santa Rita (Hibr.). Una arbustiva de relevancia ornamental. Revista de Investigaciones Agropecuarias, April 2003, vol. 32, no. 1, p. 111-122.

HORN, W. Breeding for Ornamentals. In: VAINSTEIN, A. ed. Classical and Molecular Approaches. Kluwer Academic Publisher, Netherlands, 2002, p. 47-83.

MURASHIGE, T. and SKOOG, F. A revised medium for rapid growth and bioassays with tobacco tissue cultures. Physiolgia Plantarum, 1962, vol. 15, p. 437-497.

NOTSUKA, K.; TSURU, T. and SHIRAISHI, M. Induced polyploidy in grapes via in vitro chromosome doubling. Journal of Japan Society of Horticulture Science, 2000, vol. 69 , no. 5 , p. 543-551.
ZULOAGA, F. and MORRONE, O. Catálogo de plantas vasculares de la Argentina. Missouri Botanical Garden Press. 1999. 1247 p. ISBN 0-915279-65-7. 